\title{
Beryl composition and evolution trends: an example from granitic pegmatites of the beryl-columbite subtype, Western Carpathians, Slovakia
}

\author{
Pavel UHER ${ }^{1,2^{*}}$, Peter CHUDÍK², Peter BAČíK', Tomáš VACULOVIČ3 ${ }^{3}$ Michaela GALIOVÁ ${ }^{3}$ \\ ${ }^{1}$ Department of Mineralogy and Petrology, Faculty of Natural Sciences, Comenius University, Mlynská dolina G, 84215 Bratislava, Slovakia; \\ puher@fns.uniba.sk \\ ${ }^{2}$ Department of Mineral Deposits, Faculty of Natural Sciences, Comenius University, Mlynská dolina G, 84215 Bratislava, Slovakia \\ ${ }^{3}$ Department of Chemistry, Faculty of Science, Masaryk University, Kotlářská 2, 61137 Brno, Czech Republic \\ * Corresponding author
}

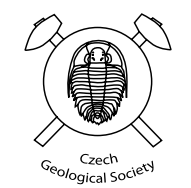

Beryl is an uncommon but characteristic mineral of Hercynian granitic pegmatites associated with S-type granitesgranodiorites of the Bratislava and Bojná massifs, Tatric Unit, Central Western Carpathians (SW Slovakia). Beryl represents the only essential rare-element phase in majority of the pegmatites, whereas accessory $\mathrm{Nb}-\mathrm{Ta}-(\mathrm{Sn})$ oxide minerals occur in the most evolved ones (Moravany nad Váhom, Jezuitské Lesy). Beryl forms columnar pale green crystals on the boundary between blocky K-feldspar zone and muscovite plus quartz core (beryl I) or locally in saccharoidal and cleavelandite albite unit (beryl II). The EMPA, LA-ICP-MS and XRD data show mostly the presence of common $\mathrm{Li}$, Cs-poor beryl with variable amounts of $\mathrm{Na}$ and occasionally small $\mathrm{Fe}, \mathrm{Mg}$-enriched domains (up to $3.5 \mathrm{wt}$ \% $\mathrm{FeO}$ and 1.8 wt. $\% \mathrm{MgO})$, with dominant channel-octahedral substitution represented by the $\mathrm{Na}\left(\mathrm{Fe}^{2+}, \mathrm{Mg}\right) \square_{-1} \mathrm{Al}_{-1}$ exchange. Beryl of the most evolved pegmatites contains moderately elevated Li (up to 5600 ppm; Moravany nad Váhom) or Cs contents (up to 9800 ppm, 1 to 2 wt. \% $\mathrm{Cs}_{2} \mathrm{O}$ in some zones; Jezuitské Lesy), which indicates also a possibility of channel-tetrahedral substitutions. A common patchy internal zoning of primary magmatic beryl I crystals represents a late-magmatic to subsolidus, partial dissolution-reprecipitation phenomenon. On the contrary, crystals of beryl II show relatively homogeneous internal texture and lower content of Cs than associated beryl I. Consequently, compositional variations and internal texture of the beryl demonstrate magmatic to subsolidus evolution of less fractionated, berylcolumbite subtype populations of the granitic pegmatites. The primary evolution trend of beryl is characterized by increasing $\mathrm{Cs}$ and $\mathrm{Cs} / \mathrm{Na}$ with decreasing $\mathrm{Mg}$ and $\mathrm{Mg} / \mathrm{Fe}$ from less evolved to more fractionated pegmatites. However, a secondary evolution trend, probably connected with post-magmatic partial dissolution-reprecipitation, shows decreasing Cs and increasing $\mathrm{Mg} / \mathrm{Fe}$ in the beryl.

Keywords: beryl, granitic pegmatites, EMPA, LA-ICP-MS, XRD, evolution trends

Received: 20 November 2009; accepted: 22 March 2010; handling editor: P. Nabelek

\section{Introduction}

Beryl represents the most abundant Be phase in the Earth's lithosphere. It is the most characteristic and widespread mineral of Be in granitic pegmatites, especially of the rare-element, beryl and complex type of the LCT ( $\mathrm{Li}-\mathrm{Cs}-\mathrm{Ta})$ suite, and less frequently in the NYF $(\mathrm{Nb}-$ Y-F) suite (Černý and Ercit 2005). Columnar pale green beryl crystals with simple morphology commonly occur in blocky pegmatite units, in close association with quartz core, microcline and muscovite, where they reach several centimetres to meters. However, locally relatively small but gem-quality beryl crystals of a great variety of colors and complex morphology (e.g., aquamarine, morganite, heliodore and goshenite varieties) occur also in pegmatite cavities or in late saccharoidal albite units of rare-element granitic pegmatites (e.g., Černý 2002; London 2008). Beryl is the first of the truly exotic, rare-element miner- als to crystallize in the evolutionary sequence of LCT rare-element pegmatites. It is a characteristic phase in the relatively less fractionated granitic pegmatites of the beryl-columbite subtype, lacking $\mathrm{Li}$ and $\mathrm{Cs}$ minerals, but commonly occurs with $\mathrm{Nb}-\mathrm{Ta}$ oxide minerals, especially with members of the columbite group (e.g., Černý 1989 , 2002). Such pegmatite populations are usually closely connected with their parental granitic rocks; the pegmatite dikes are usually situated within the granites or in adjacent metamorphic rocks, in close proximity to the granite exocontact.

The Hercynian granitic pegmatites of the West-Carpathian province, Slovakia (Uher 1994), represent a typical example of the less evolved beryl-columbite subtype with the presence of beryl and $\mathrm{Nb}$-Ta oxide minerals in the most evolved dikes (e.g., Uher 1991; Uher and Broska 1995). In contrast to several detailed studies devoted to the composition of $\mathrm{Nb}-\mathrm{Ta}$ phases (e.g., Uher et al. 1994, 
1998a, b, 2007; Novák et al. 2000), only limited descriptions of beryl exist for the West Carpathian pegmatites (e.g., Gargulák and Vanek 1989; Broska and Uher 1995; Uher and Benko 1997). Consequently, the aim of this study is to characterize the beryl occurrences, properties (lattice parameters, variations of chemical composition), as well as their internal zoning as a tool for understanding the magmatic to post-magmatic (subsolidus) evolution of the parental granitic pegmatite dikes.

\section{Geological setting}

The beryl-bearing granitic pegmatites have been discovered mainly in S-type peraluminous granitic massifs. The first finding of beryl was described in a pegmatite near Sklené in the Žiar Mountains (Fiala 1931). However, the pegmatites with beryl occur mainly in the area between Bratislava and Borinka, the Bratislava Massif of the Malé Karpaty Mountains (Gargulák and Vanek 1989; Uher 1994; Uher and Broska 1995), and near Moravany nad Váhom at the Bojná Massif of the Považský Inovec Mts. (Uher 1991, 1992; Uher and Broska 1995). In addition, more evolved I-type biotite granodiorites to granites of the Prašivá intrusion in the Nízke Tatry Mts. also contain pegmatite dikes with beryl (Pitoňák and Janák 1983; Uher 1992; Uher and Benko 1997). Our study is focused on the beryl occurrences in granitic pegmatites from the Bratislava and Bojná massifs of the Malé Karpaty and Považský Inovec mountains, southwestern Slovakia (Fig. 1).

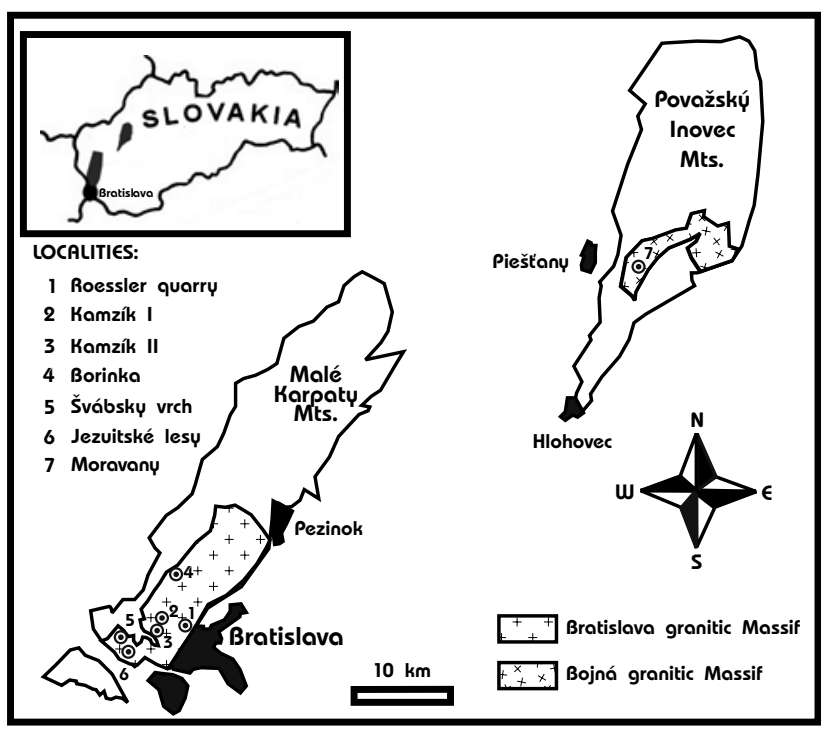

Fig. 1 Locations of granitic pegmatites hosting investigated beryl in the Bratislava and Bojná massifs.
The beryl-bearing pegmatites occur as true dikes or lensoid bodies in parental granitic rocks and in adjacent metamorphic rocks in close exocontact with the granite intrusions. The thickness of the pegmatites generally attains from 0.5 to $2 \mathrm{~m}$, and locally up to $8 \mathrm{~m}$ (Moravany nad Váhom pegmatite). The pegmatites show internal zoning, commonly with an aplitic to coarse-grained quartz-feldspar-muscovite (biotite) border unit, an intermediate zone with coarse-grained to blocky K-feldspar ( \pm quartz, muscovite or biotite), and quartz core zone. Locally, irregular late albite-rich assemblages with dominant saccharoidal albite or cleavelandite partially replace older units (e.g., Moravany nad Váhom, Jezuitské Lesy pegmatite).

The pegmatites with adjacent granitic and metamorphic rocks are part of the pre-Alpine crystalline basement of the Tatric Superunit of the Central Western Carpathians, which was incorporated into a younger thrust and nappe tectonic structure of the Alpine (Cretaceous to Neogene) orogenic belt.

The parental granitic rocks are biotite to biotitemuscovite granites, granodiorites, and rare leucotonalites which display peraluminous, calc-alkaline trend and Sto I-type geochemical affinities (e.g., Broska and Uher 2001; Petrík et al. 2001). Locally more evolved muscovite-(biotite) leucogranites, pegmatitic leucogranites and aplites occur in apophyses and/or dikes of the granitic massifs. The pegmatite-bearing granitic rocks show a Mississippian (Early Carboniferous) age of emplacement, usually around $350 \mathrm{Ma}$ from zircon and monazite U-Th- $\mathrm{Pb}$ isotope or chemical dating (Petrík et al. 2001; Finger et al. 2003).

The adjacent metamorphic rocks usually represent Lower Paleozoic, mainly Silurian to Devonian metapelites to metapsammites of the amphibolite facies (biotite-, garnet-, staurolite- and sillimanite-bearing micaschists to paragneisses), and locally metabasic rocks (amphibolites). Emplacement depths of 12-15 km were estimated on the basis of index minerals in the thermal aureole of granitic intrusions (Korikovsky et al. 1984; Krist et al. 1992).

\section{Analytical methods}

The minerals in polished sections were analyzed with a Cameca SX 100 electron microprobe using the wavedispersion mode (WDS) and imaged using back-scattered electrons (BSE) at the Geological Survey of the Slovak Republic, Bratislava. The following analytical conditions were applied: $15 \mathrm{kV}$ accelerating voltage, $20 \mathrm{nA}$ beam current, and 5-10 $\mu \mathrm{m}$ beam diameter. Standards used included wollastonite $(\mathrm{Si}, \mathrm{Ca}), \mathrm{TiO}_{2}(\mathrm{Ti}), \mathrm{Al}_{2} \mathrm{O}_{3}(\mathrm{Al}), \mathrm{V}_{2} \mathrm{O}_{3}(\mathrm{~V})$, $\mathrm{Cr}_{2} \mathrm{O}_{3}(\mathrm{Cr})$, fayalite $(\mathrm{Fe})$, rhodonite $(\mathrm{Mn})$, willemite $(\mathrm{Zn})$, 
forsterite $(\mathrm{Mg})$, albite $(\mathrm{Na})$, orthoclase $(\mathrm{K}), \mathrm{Rb}_{2} \mathrm{ZnSi}_{5} \mathrm{O}_{12}$ glass $(\mathrm{Rb})$, pollucite $(\mathrm{Cs})$, and $\mathrm{LiF}(\mathrm{F})$. Counting times of 20 to 40 seconds were used. The detection limits of measured elements range from 0.02 to $0.1 \mathrm{wt} . \%$, and statistical errors from 0.02 to $0.08 \mathrm{wt} \%(1 \sigma)$, depending on the elemental concentration. The electron-microprobe analytical data were reduced using the PAP routine (Pouchou and Pichoir 1985). Beryl compositions in oxide wt. \% were calculated into empirical formulae on the basis of 18 oxygen atoms, and the $\mathrm{Be}$ and $\mathrm{BeO}$ contents were computed on the basis of an ideal sum of $\mathrm{Be}=3$ atoms per formula unit. All iron was calculated as $\mathrm{Fe}^{2+}$ and $\mathrm{FeO}$, however, some $\mathrm{Fe}^{3+}$ in the beryl structure may be present.

Instrumentation for LA-ICP-MS at the Department of Chemistry, Masaryk University, Brno, consists of a laser ablation system UP 213 (New Wave, USA) and an ICP-MS spectrometer Agilent 7500 CE (Agilent, Japan). A commercial Q-switched Nd-YAG laser-ablation device works at the $5^{\text {th }}$ harmonic frequency that corresponds to the wavelength of $213 \mathrm{~nm}$. The ablation device is equipped with programmable XYZ-stage to move the sample along a programmed trajectory during ablation. Target visual inspection as well as photographic documentation is accomplished by means of a built-in microscope/CCD-camera system. A sample was enclosed in the SuperCell (New Wave, USA) and was ablated by the laser beam, which was focused onto the sample surface through a quartz window. The ablation cell was flushed with helium (carrier gas) that transported the laser-induced aerosol to the inductively coupled plasma
(1.0 $\mathrm{l} / \mathrm{min})$. A sample gas flow of argon was admixed to the helium carrier gas flow behind the laser ablation cell. Therefore, the total gas flow was $1.6 \mathrm{l} / \mathrm{min}$. Optimization of LA-ICP-MS conditions (gas flow rates, sampling depth, electrostatic lenses voltages of the MS) was performed with the glass reference material NIST SRM 612 in respect to the maximum signal to noise ratio and minimum oxide formation $\left(\mathrm{ThO}^{+} / \mathrm{Th}^{+}\right.$counts ratio 0.2 $\%, \mathrm{U}^{+} / \mathrm{Th}^{+}$counts ratio $1.1 \%$ ). Hole drilling mode (fixed sample position during laser ablation) for the duration of 60 seconds was used for each spot. Laser ablation was performed with laser spot diameter $80 \mu \mathrm{m}$, laser fluence $5.5 \mathrm{~J} \mathrm{~cm}^{-2}$ and repetition rate $10 \mathrm{~Hz}$. All element measurements were normalized on ${ }^{28} \mathrm{Si}$.

Powder X-ray diffraction analyses were made on diffractometer BRUKER D8 Advance (Laboratory of $\mathrm{X}$-ray diffraction SOLIPHA, Comenius University in Bratislava, Faculty of Natural Sciences) under following conditions: Bragg-Brentano geometry (Theta-2 Theta), $\mathrm{Cu}$ anticathode $\left(\lambda_{\alpha 1}=1.5406010^{-10} \mathrm{~m}\right)$, accelerating voltage $40 \mathrm{kV}$, beam current $40 \mathrm{~mA}$. Ni $\mathrm{K}_{\beta}$ filter was used for stripping of $\mathrm{K}_{\beta}$ radiation on the primary and diffracted beams, and data were obtained by the BRUKER LynxEye detector. The step size was $0.01^{\circ} 2 \Theta$, the step time was $5 \mathrm{~s}$ per one step, and the range of measurement was $4-65^{\circ}$ $2 \Theta$. Measured data were evaluated with DIFFRAC ${ }^{\text {plus }}$ EVA software package. The cell parameters were calculated using the non-linear least squares cell refinement UnitCell program with regression diagnostics (Holland and Redfern 1997).
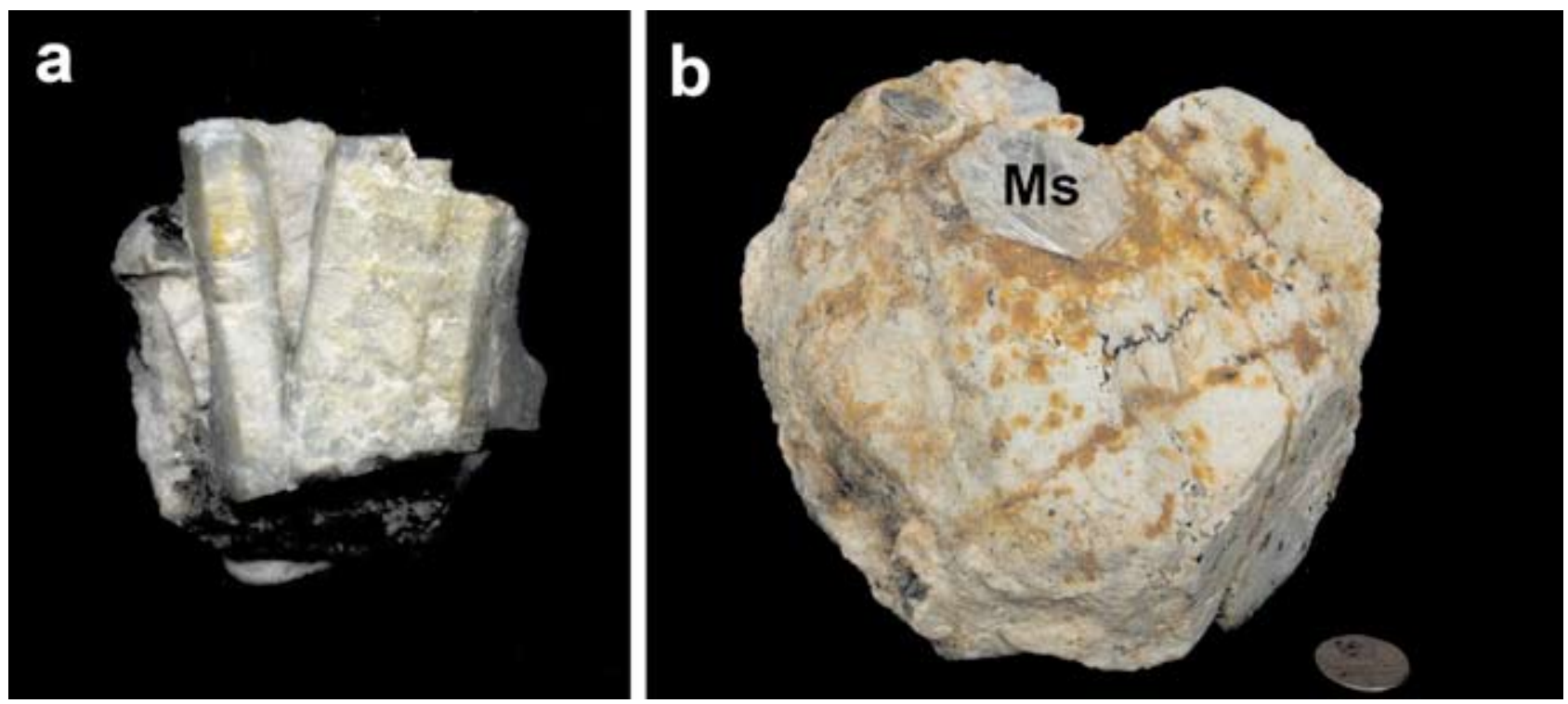

Fig. 2a - Columnar crystals of beryl (3 cm long) in blocky quartz. Bratislava, Kamzík II pegmatite. b - Fragment of hexagonal beryl crystal (15 $\mathrm{cm}$ in size) with muscovite (Ms) in the Moravany nad Váhom pegmatite. 


\section{Results}

\subsection{Beryl occurrence}

Beryl was found in two paragenetic units within the studied granitic pegmatites. Beryl I occurs in coarse to blocky quartz + K-feldspar (rarely albite) + muscovite unit or in blocky quartz core in the all investigated localities, and beryl II occurs in finely-crystalline saccharoidal albite $\left(\mathrm{An}_{00-01}\right)$ in association with subordinate quartz and muscovite and platy albite (cleavelandite), in the Devín, Jezuitské Lesy pegmatite. Textural evidence indicates a late-magmatic origin of the saccharoidal albite unit; it metasomatically replaced older magmatic units of the pegmatite dikes.

Beryl I forms typical hexagonal crystals with a columnar habit, usually 1 to $5 \mathrm{~cm}$ but up to $15 \mathrm{~cm}$ in size, in association with blocky quartz and tabular muscovite crystals (Fig. 2). The crystals are semi-transparent, with pale green to yellow-green colour. The beryl crystals are commonly partially altered, without glassy lustre in the Moravany nad Váhom pegmatite. Rarely, beryl crystals occur with black, finely-crystalline Fe-rich biotite-chlorite aggregates in the Dúbravka, Švábsky Hill (Švábsky vrch) pegmatite. Minute inclusions of quartz, albite, K-feldspar, muscovite, gahnite, sphalerite/wurtzite and chamosite(?) were found in beryl I (Fig. 3a-b).

Beryl II forms hexagonal prismatic crystals, usually 0.5 to $1 \mathrm{~cm}$ in size. In comparison with beryl I, crystals of beryl II commonly are more elongated and show deeper green colour. It occurs with adjacent albite, quartz, muscovite, and rare small crystals of almandine-spessartine, gahnite and ferrocolumbite in the Devín, Jezuitské Lesy pegmatite.

\subsection{Internal zoning, composition and cell parameters of beryl}

Beryl crystals in thin sections are nearly unzoned but in some cases zoning appears in BSE images. Homogeneous crystals of beryl I, only locally with negligible diffuse zoning, occur in the majority of the investigated pegmatite dikes (Moravany nad Váhom, Švábsky Hill, Kamzík I and II, Roessler quarry).

Regular, primary concentric growth zoning was observed in some crystals of beryl I from the Devín, Jezuitské Lesy pegmatite. However, this apparently primary magmatic feature was overprinted by secondary irregular patchy zoning, mainly along cracks (Fig. 3c). The primary growth zones show variations between 0.4 and 1.9 wt. \% in $\mathrm{Cs}_{2} \mathrm{O}$ (0.02 to 0.08 apfu Cs), whereas the secondary patches contain only 0.2 to 0.5 wt. $\% \mathrm{Cs}_{2} \mathrm{O}(0.01$ to 0.02 apfu $\mathrm{Cs})$. The $\mathrm{Na}, \mathrm{Rb}$ and $\mathrm{Fe}$ concentrations are approximately equal (Tab. 1). In some cases, only small relicts of primary zoning are preserved and the secondary patchy texture dominates in beryl I (Fig. 3d).

Distinctly irregular domains of Fe-Mg-rich beryl, 30 $\mu \mathrm{m}$ in size, are developed around muscovite and quartz inclusions in beryl I of the Dúbravka, Švábsky Hill pegmatite (Fig. 3e). The Fe-Mg-rich zone contains 3.5 wt. $\% \mathrm{FeO}(0.27$ apfu Fe) and 1.8 wt. \% $\mathrm{MgO}(0.24 \mathrm{apfu}$ $\mathrm{Mg})$, in contrast to adjacent beryl that contains only 0.5 wt. \% FeO (0.04 apfu Fe) and 0.5 wt. \% MgO (0.07 apfu $\mathrm{Mg})$. The domain probably represents a reaction aureole between primary beryl and Fe- and Mg-rich phengitic muscovite (with 8.4 wt. \% FeO, 0.46 apfu Fe and 2.3 wt. $\% \mathrm{MgO}, 0.23$ apfu Mg).

Beryl II, which is in association with saccharoidal albite zone (Devín, Jezuitské Lesy pegmatite), shows mostly unzoned BSE pattern with faint diffusion zones only along the contact with quartz and K-feldspar (Fig. 3f). These zones are enriched in $\mathrm{Cs}$ in comparison to the rest of beryl II (0.6-0.7 and 0.1 wt. $\% \mathrm{Cs}_{2} \mathrm{O}$, respectively; Tab. 1).

Trace element compositions of the studied beryl show relatively wide variations (Tab. 2). Concentrations of $\mathrm{Li}$ are typically 120 to $830 \mathrm{ppm}$, locally 1400 to $1800 \mathrm{ppm}$ (Švábsky Hill, Kamzík II). The highest Li contents shows beryl from the Moravany nad Váhom pegmatite (up to $5600 \mathrm{ppm})$. On the other hand, the highest concentrations of Cs (5700 to $9800 \mathrm{ppm}$ ) occur in beryl I from the Jezuitské Lesy pegmatite, whereas other investigated samples contain only $\sim 50$ to 1400 ppm Cs (Tab. 2). Locally beryl also contains slightly elevated contents of $\mathrm{K}$ (1300 to $2300 \mathrm{ppm})$ and $\mathrm{Zn}(\sim 900$ to $1700 \mathrm{ppm}$ in beryl I from Jezuitské Lesy pegmatite). Rubidium and manganese concentrations are generally low $(\leq 170 \mathrm{ppm}$ $\mathrm{Rb}, \leq 280 \mathrm{ppm} \mathrm{Mn}$ ), contents of Sc, Ga and Ni are lower than $100 \mathrm{ppm}$, and approaching the detection limit of the LA-ICP-MS method for other measured elements ( $\mathrm{Sr}, \mathrm{Ba}$, $\mathrm{V}, \mathrm{Cr}, \mathrm{Cu}, \mathrm{Co}, \mathrm{Cd}, \mathrm{REE}, \mathrm{Sn}, \mathrm{Ti}, \mathrm{Zr}, \mathrm{Hf}, \mathrm{Nb}, \mathrm{Ta}, \mathrm{As}, \mathrm{Sb}$, $\mathrm{Bi}, \mathrm{W}, \mathrm{Th}, \mathrm{U}$ and $\mathrm{Pb}$ ).

Distribution and mutual relationships between major measured elements ( $\mathrm{Al}, \mathrm{Fe}, \mathrm{Mg}, \mathrm{Na}$ and $\mathrm{Cs}$ ) show the dominant role of $\mathrm{Na}\left(\mathrm{Fe}^{2+}, \mathrm{Mg}\right) \square_{-1} \mathrm{Al}_{-1}$ channel-octahedral substitution mechanism in the beryl compositions: (Fig. 4a-b). However, elevated $\mathrm{Li}$ or $\mathrm{Cs}$ contents also indicate the presence of some channel-tetrahedral substitutions in beryl in the most evolved pegmatites possibly ( $\mathrm{Na}, \mathrm{Cs}) \mathrm{Li} \square{ }_{-1} \mathrm{Be}_{-1}$ in the Moravany nad Váhom and $(\mathrm{Cs}, \mathrm{Na}) \mathrm{Al} \square_{-1} \mathrm{Si}_{-1}$ in the Jezuitské Lesy pegmatite (Fig. 4c).

The XRD determinations support the compositional data and these substitution mechanisms. They show similar cell parameters for all studied pegmatite occurrences (Tab. 3, Fig. 5). However, the calculated $c / a$ ratio (Aurisicchio et al. 1988) reflects the presence of tetrahedral 

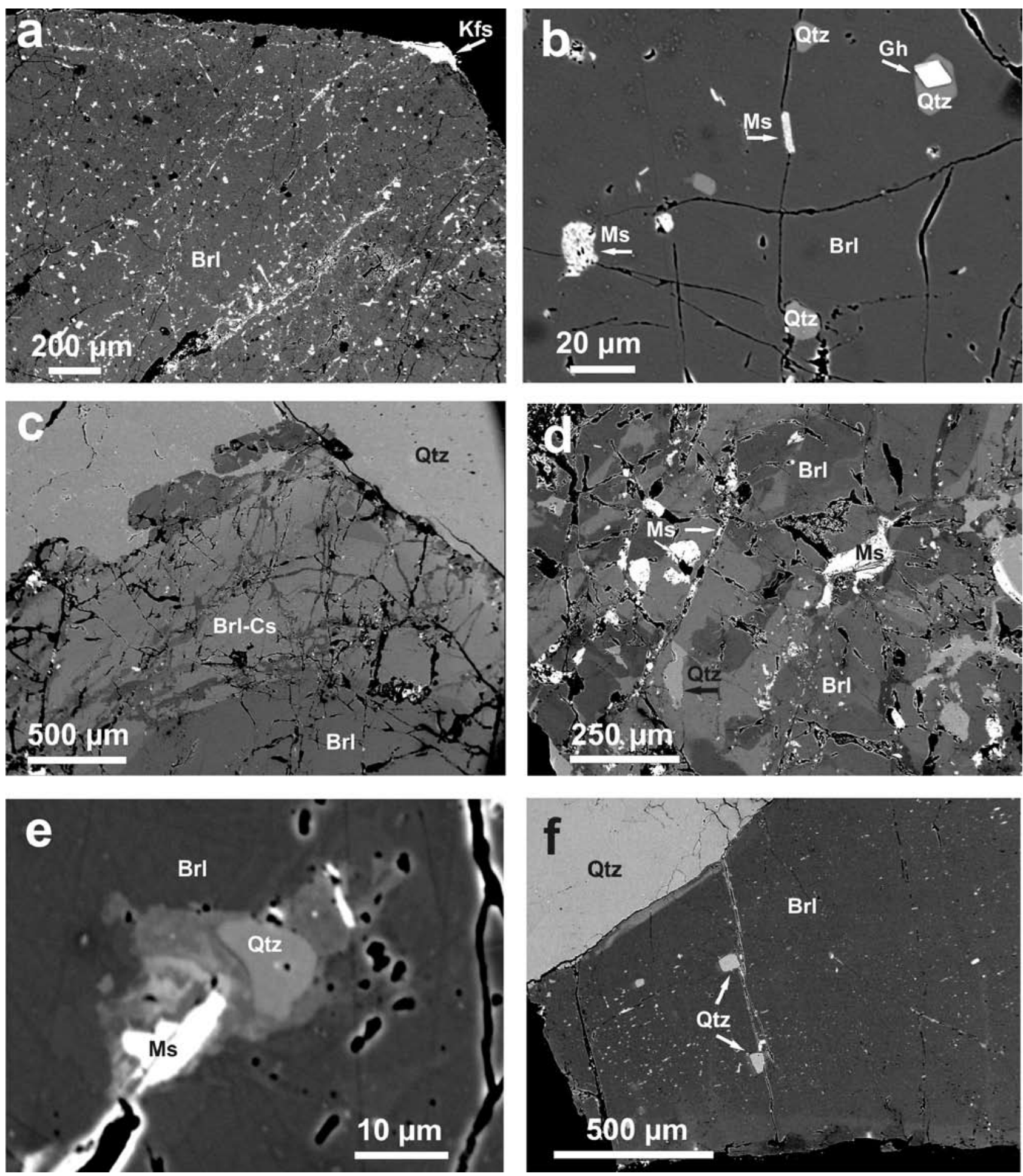

Fig. 3 Back-scattered electron (BSE) photomicrographs of beryl (Brl) from granitic pegmatites of the Bratislava and Bojná massifs. a - Beryl I with tiny inclusions of quartz, albite and K-feldspar (Kfs). b - Beryl I with inclusions of gahnite (Gh), muscovite (Ms) and quartz (Qtz). c - Regular zoning of Cs-bearing beryl I (Brl-Cs), overprinted by secondary irregular zoning, veinlets and rim zones in quartz. d - Irregular secondary zoning of beryl I with remnants of primary texture and inclusions of muscovite and quartz. e - Beryl I with Fe-Mg-rich domain around Fe-Mg-rich muscovite and quartz inclusions. f - Beryl II with tiny inclusions of quartz and muscovite and rim zone in contact with quartz. 
Tab. 1. Representative compositions of beryl from granitic pegmatites of the Bratislava and Bojná massifs (in wt. \%). Beryl type: beryl I primary zones (IP), beryl I secondary zones (IS), beryl II cores (IIC), beryl II rims (IIR).

\begin{tabular}{|c|c|c|c|c|c|c|c|c|}
\hline $\begin{array}{l}\text { Locality } \\
\text { Beryl type }\end{array}$ & \multicolumn{2}{|c|}{ Roessler quarry } & \multicolumn{2}{|c|}{ Kamzík I } & \multicolumn{2}{|c|}{ Kamzík II } & \multicolumn{2}{|c|}{ Borinka } \\
\hline Sample \# & BM-3.37 & BM-3.39 & BM-8a & BM-8b & BM-23.43 & BM-23.44 & BM-9.2 & BM-9.3 \\
\hline $\mathrm{SiO}_{2}$ & 66.46 & 66.79 & 65.74 & 67.12 & 68.01 & 67.42 & 66.01 & 66.35 \\
\hline $\mathrm{TiO}_{2}$ & 0.00 & 0.00 & 0.00 & 0.00 & 0.00 & 0.00 & 0.00 & 0.00 \\
\hline $\mathrm{Al}_{2} \mathrm{O}_{3}$ & 18.09 & 17.91 & 17.79 & 18.08 & 18.38 & 18.28 & 18.00 & 17.62 \\
\hline $\mathrm{V}_{2} \mathrm{O}_{3}$ & 0.00 & 0.00 & & & 0.00 & 0.00 & 0.00 & 0.04 \\
\hline $\mathrm{Cr}_{2} \mathrm{O}_{3}$ & 0.00 & 0.00 & 0.00 & 0.00 & 0.00 & 0.00 & 0.00 & 0.00 \\
\hline $\mathrm{FeO}$ & 0.54 & 0.63 & 0.34 & 0.27 & 0.31 & 0.63 & 0.32 & 0.55 \\
\hline $\mathrm{MnO}$ & 0.03 & 0.04 & 0.00 & 0.00 & 0.03 & 0.00 & 0.00 & 0.00 \\
\hline $\mathrm{ZnO}$ & 0.08 & 0.08 & & & 0.00 & 0.00 & 0.00 & 0.00 \\
\hline $\mathrm{BeO}$ calc. & 13.82 & 13.87 & 13.61 & 13.88 & 14.09 & 14.01 & 13.77 & 13.80 \\
\hline $\mathrm{MgO}$ & 0.14 & 0.22 & 0.03 & 0.00 & 0.06 & 0.09 & 0.24 & 0.44 \\
\hline $\mathrm{CaO}$ & 0.00 & 0.00 & 0.00 & 0.00 & 0.00 & 0.00 & 0.00 & 0.00 \\
\hline $\mathrm{Na}_{2} \mathrm{O}$ & 0.35 & 0.37 & 0.27 & 0.25 & 0.34 & 0.44 & 0.61 & 0.67 \\
\hline $\mathrm{K}_{2} \mathrm{O}$ & 0.00 & 0.00 & 0.00 & 0.00 & 0.00 & 0.00 & 0.00 & 0.04 \\
\hline $\mathrm{Rb}_{2} \mathrm{O}$ & 0.02 & 0.02 & & & 0.03 & 0.03 & 0.26 & 0.24 \\
\hline $\mathrm{Cs}_{2} \mathrm{O}$ & 0.11 & 0.26 & & & 0.06 & 0.00 & 0.07 & 0.14 \\
\hline $\mathrm{F}$ & 0.00 & 0.00 & 0.00 & 0.00 & 0.00 & 0.00 & 0.17 & 0.00 \\
\hline $\mathrm{O}=\mathrm{F}$ & 0.00 & 0.00 & 0.00 & 0.00 & 0.00 & 0.00 & -0.07 & 0.00 \\
\hline Total & 99.64 & 100.19 & 97.78 & 99.60 & 101.31 & 100.90 & 99.38 & 99.89 \\
\hline
\end{tabular}

Formulae based on 18 oxygen atoms and $\mathrm{Be}=3$ atoms

\begin{tabular}{|c|c|c|c|c|c|c|c|c|}
\hline $\mathrm{Si}$ & 6.005 & 6.013 & 6.030 & 6.041 & 6.028 & 6.011 & 5.985 & 6.003 \\
\hline $\mathrm{Be}$ & 3.000 & 3.000 & 3.000 & 3.000 & 3.000 & 3.000 & 3.000 & 3.000 \\
\hline $\mathrm{Ti}$ & 0.000 & 0.000 & 0.000 & 0.000 & 0.000 & 0.000 & 0.000 & 0.000 \\
\hline $\mathrm{Al}$ & 1.926 & 1.900 & 1.923 & 1.918 & 1.920 & 1.921 & 1.924 & 1.879 \\
\hline $\mathrm{V}$ & 0.000 & 0.000 & & & 0.000 & 0.000 & 0.000 & 0.003 \\
\hline $\mathrm{Cr}$ & 0.000 & 0.000 & 0.000 & 0.000 & 0.000 & 0.000 & 0.000 & 0.000 \\
\hline $\mathrm{Fe}$ & 0.041 & 0.047 & 0.026 & 0.020 & 0.023 & 0.047 & 0.024 & 0.042 \\
\hline $\mathrm{Mn}$ & 0.002 & 0.003 & 0.000 & 0.000 & 0.002 & 0.000 & 0.000 & 0.000 \\
\hline $\mathrm{Zn}$ & 0.005 & 0.005 & & & 0.000 & 0.000 & 0.000 & 0.000 \\
\hline $\mathrm{Mg}$ & 0.019 & 0.030 & 0.004 & 0.000 & 0.008 & 0.012 & 0.032 & 0.059 \\
\hline Sum $O$ & 1.993 & 1.985 & 1.953 & 1.938 & 1.953 & 1.980 & 1.980 & 1.983 \\
\hline $\mathrm{Ca}$ & 0.000 & 0.000 & 0.000 & 0.000 & 0.000 & 0.000 & 0.000 & 0.000 \\
\hline $\mathrm{Na}$ & 0.061 & 0.065 & 0.048 & 0.044 & 0.058 & 0.076 & 0.107 & 0.118 \\
\hline K & 0.000 & 0.000 & 0.000 & 0.000 & 0.000 & 0.000 & 0.000 & 0.005 \\
\hline $\mathrm{Rb}$ & 0.001 & 0.001 & & & 0.002 & 0.002 & 0.015 & 0.014 \\
\hline $\mathrm{Cs}$ & 0.004 & 0.010 & & & 0.002 & 0.000 & 0.003 & 0.005 \\
\hline Sum $C$ & 0.066 & 0.076 & 0.048 & 0.044 & 0.062 & 0.078 & 0.125 & 0.142 \\
\hline Vac. $C$ & 0.934 & 0.924 & 0.952 & 0.956 & 0.938 & 0.922 & 0.875 & 0.858 \\
\hline Cat. Sum & 11.065 & 11.075 & 11.032 & 11.022 & 11.043 & 11.068 & 11.091 & 11.127 \\
\hline $\mathrm{F}$ & 0.000 & 0.000 & 0.000 & 0.000 & 0.000 & 0.000 & 0.049 & 0.000 \\
\hline
\end{tabular}


Tab. 1. Continued

\begin{tabular}{|c|c|c|c|c|c|c|c|c|}
\hline \multirow{2}{*}{$\begin{array}{l}\text { Locality } \\
\text { Beryl type }\end{array}$} & \multicolumn{2}{|c|}{ Švábsky Hill } & \multicolumn{2}{|c|}{ Moravany n. Váhom } & \multicolumn{4}{|c|}{ Jezuitské Lesy } \\
\hline & & & & & IP & IS & IIC & IIR \\
\hline Sample \# & BM-21.1 & BM-21.2 & PI-15.1 & PI-15.5 & BMD-1.5 & BMD-1.7 & BMD-2.2 & BMD-2.14 \\
\hline $\mathrm{SiO}_{2}$ & 65.93 & 66.92 & 66.75 & 67.27 & 65.72 & 66.53 & 66.78 & 66.78 \\
\hline $\mathrm{TiO}_{2}$ & 0.00 & 0.00 & 0.00 & 0.00 & & & & \\
\hline $\mathrm{Al}_{2} \mathrm{O}_{3}$ & 13.67 & 17.77 & 17.75 & 17.73 & 17.86 & 18.00 & 18.41 & 17.93 \\
\hline $\mathrm{V}_{2} \mathrm{O}_{3}$ & 0.00 & 0.00 & 0.00 & 0.00 & & & & \\
\hline $\mathrm{Cr}_{2} \mathrm{O}_{3}$ & 0.00 & 0.00 & 0.00 & 0.00 & & & & \\
\hline $\mathrm{FeO}$ & 3.49 & 0.40 & 0.40 & 0.43 & 0.49 & 0.35 & 0.31 & 0.56 \\
\hline $\mathrm{MnO}$ & 0.00 & 0.00 & 0.00 & 0.00 & & & & \\
\hline $\mathrm{ZnO}$ & 0.00 & 0.00 & 0.00 & 0.00 & 0.12 & 0.07 & 0.05 & 0.09 \\
\hline $\mathrm{BeO}$ calc. & 13.49 & 13.89 & 13.80 & 13.92 & 13.70 & 13.89 & 13.91 & 13.88 \\
\hline $\mathrm{MgO}$ & 1.76 & 0.39 & 0.16 & 0.19 & 0.00 & 0.11 & 0.02 & 0.08 \\
\hline $\mathrm{CaO}$ & 0.00 & 0.00 & 0.00 & 0.00 & & & & \\
\hline $\mathrm{Na}_{2} \mathrm{O}$ & 0.45 & 0.69 & 0.25 & 0.36 & 0.63 & 1.45 & 0.54 & 0.63 \\
\hline $\mathrm{K}_{2} \mathrm{O}$ & 0.00 & 0.00 & 0.00 & 0.00 & 0.04 & 0.00 & 0.03 & 0.03 \\
\hline $\mathrm{Rb}_{2} \mathrm{O}$ & 0.00 & 0.00 & 0.00 & 0.00 & 0.14 & 0.12 & 0.10 & 0.10 \\
\hline $\mathrm{Cs}_{2} \mathrm{O}$ & 0.00 & 0.07 & 0.05 & 0.03 & 1.96 & 0.29 & 0.13 & 0.63 \\
\hline $\mathrm{F}$ & 0.00 & 0.00 & 0.00 & 0.19 & & & & \\
\hline $\mathrm{O}=\mathrm{F}$ & 0.00 & 0.00 & 0.00 & -0.08 & & & & \\
\hline Total & 98.79 & 100.13 & 99.16 & 100.04 & 100.66 & 100.81 & 100.28 & 100.71 \\
\hline
\end{tabular}

Formulae based on 18 oxygen atoms and $\mathrm{Be}=3$ atoms

\begin{tabular}{|c|c|c|c|c|c|c|c|c|}
\hline $\mathrm{Si}$ & 6.104 & 6.016 & 6.042 & 6.036 & 5.989 & 5.979 & 5.997 & 6.009 \\
\hline $\mathrm{Be}$ & 3.000 & 3.000 & 3.000 & 3.000 & 3.000 & 3.000 & 3.000 & 3.000 \\
\hline $\mathrm{Ti}$ & 0.000 & 0.000 & 0.000 & 0.000 & & & & \\
\hline $\mathrm{Al}$ & 1.492 & 1.883 & 1.894 & 1.875 & 1.918 & 1.907 & 1.948 & 1.901 \\
\hline $\mathrm{V}$ & 0.000 & 0.000 & 0.000 & 0.000 & & & & \\
\hline $\mathrm{Cr}$ & 0.000 & 0.000 & 0.000 & 0.000 & & & & \\
\hline $\mathrm{Fe}$ & 0.270 & 0.030 & 0.030 & 0.032 & 0.037 & 0.026 & 0.023 & 0.042 \\
\hline $\mathrm{Mn}$ & 0.000 & 0.000 & 0.000 & 0.000 & & & & \\
\hline $\mathrm{Zn}$ & 0.000 & 0.000 & 0.000 & 0.000 & 0.008 & 0.005 & 0.003 & 0.006 \\
\hline $\mathrm{Mg}$ & 0.243 & 0.052 & 0.022 & 0.025 & 0.000 & 0.015 & 0.003 & 0.011 \\
\hline Sum $O$ & 2.005 & 1.965 & 1.946 & 1.932 & 1.963 & 1.953 & 1.977 & 1.960 \\
\hline $\mathrm{Ca}$ & 0.000 & 0.000 & 0.000 & 0.000 & & & & \\
\hline $\mathrm{Na}$ & 0.081 & 0.120 & 0.044 & 0.063 & 0.111 & 0.253 & 0.094 & 0.110 \\
\hline K & 0.000 & 0.000 & 0.000 & 0.000 & 0.005 & 0.000 & 0.003 & 0.003 \\
\hline $\mathrm{Rb}$ & 0.000 & 0.000 & 0.000 & 0.000 & 0.008 & 0.007 & 0.006 & 0.006 \\
\hline Cs & 0.000 & 0.003 & 0.002 & 0.001 & 0.076 & 0.011 & 0.005 & 0.024 \\
\hline Sum $C$ & 0.081 & 0.123 & 0.046 & 0.064 & 0.200 & 0.271 & 0.108 & 0.143 \\
\hline Vac. $C$ & 0.919 & 0.877 & 0.954 & 0.936 & 0.800 & 0.729 & 0.892 & 0.857 \\
\hline Cat. Sum & 11.190 & 11.104 & 11.034 & 11.032 & 11.152 & 11.203 & 11.083 & 11.112 \\
\hline F & 0.000 & 0.000 & 0.000 & 0.054 & 0.000 & 0.000 & 0.000 & 0.000 \\
\hline
\end{tabular}


Tab. 2. Trace-element contents of beryl from granitic pegmatites of the Bratislava and Bojná massifs (in ppm).

\begin{tabular}{|c|c|c|c|c|c|c|c|c|c|}
\hline \multirow[t]{3}{*}{ Element } & \multirow{3}{*}{$\begin{array}{c}\text { Detection } \\
\text { limit }\end{array}$} & \multirow{3}{*}{$\begin{array}{c}\text { Roessler Q. } \\
\begin{array}{c}\text { BM-3 } \\
\text { n }=3\end{array}\end{array}$} & \multirow{3}{*}{$\begin{array}{c}\text { Kamzík I } \\
\text { BM-8 } \\
\text { n }=2\end{array}$} & \multirow{3}{*}{$\begin{array}{c}\text { Kamzík II } \\
\text { BM-23 } \\
\text { n }=3\end{array}$} & \multirow{3}{*}{$\begin{array}{c}\text { Borinka } \\
\text { BM-9 } \\
\mathrm{n}=2\end{array}$} & \multirow{3}{*}{$\begin{array}{c}\text { Švábsky H. } \\
\text { BM-21 } \\
\text { n }=6\end{array}$} & \multirow{3}{*}{$\begin{array}{c}\text { Moravany } \\
\text { PI-15 } \\
\mathrm{n}=5\end{array}$} & \multirow{3}{*}{$\begin{array}{c}\text { Jez. Lesy B-I } \\
\begin{array}{c}\text { BM-22 } \\
\text { n }=3\end{array}\end{array}$} & \multirow{3}{*}{$\begin{array}{c}\text { Jez. Lesy B-II } \\
\begin{array}{c}\text { BM-22 } \\
\text { n }=3\end{array}\end{array}$} \\
\hline & & & & & & & & & \\
\hline & & & & & & & & & \\
\hline $\mathrm{Li}$ & $17-34$ & $271-452$ & $332-831$ & $867-1818$ & $126-301$ & $649-1406$ & $339-5600$ & $394-477$ & $270-399$ \\
\hline K & $20-46$ & $61-2281$ & $215-751$ & $175-1293$ & $82-113$ & $117-2637$ & $31-1863$ & $33-108$ & $97-269$ \\
\hline $\mathrm{Rb}$ & $0.4-1$ & $19-27$ & 11 & $7-12$ & $27-35$ & $26-42$ & $4-52$ & $92-165$ & $64-131$ \\
\hline $\mathrm{Cs}$ & $0.2-2$ & $779-1385$ & $50-358$ & $68-179$ & $144-660$ & $308-1038$ & $105-357$ & 5749-9762 & $784-958$ \\
\hline $\mathrm{Sc}$ & $2-4$ & 0 & 4 & $1-10$ & $5-8$ & $2-4$ & $3-5$ & $2-5$ & $3-5$ \\
\hline $\mathrm{Ga}$ & $0.4-1$ & $14-24$ & $10-27$ & $10-20$ & $7-8$ & $9-21$ & $3-10$ & $16-25$ & $11-17$ \\
\hline $\mathrm{Mn}$ & $1-20$ & $35-70$ & $18-26$ & $81-108$ & $31-51$ & $10-65$ & $11-44$ & $80-132$ & $49-278$ \\
\hline $\mathrm{Ni}$ & $2-5$ & $26-30$ & $15-27$ & $13-37$ & $21-39$ & $12-41$ & $5-14$ & $20-29$ & $16-20$ \\
\hline $\mathrm{Zn}$ & $2-14$ & $253-766$ & $151-278$ & $331-338$ & $172-456$ & $190-479$ & $39-204$ & $875-1656$ & $615-806$ \\
\hline $\mathrm{Cs} / \mathrm{Rb}$ & & $34-71$ & $4-34$ & $6-23$ & $5-19$ & $10-25$ & $7-34$ & $35-104$ & $7-14$ \\
\hline $\mathrm{Li} / \mathrm{Cs}$ & & $0.2-0.6$ & $2.3-6.7$ & $5.3-24$ & $0.5-0.9$ & $0.9-2.3$ & $1.0-42$ & $0.04-0.08$ & $0.3-0.5$ \\
\hline
\end{tabular}
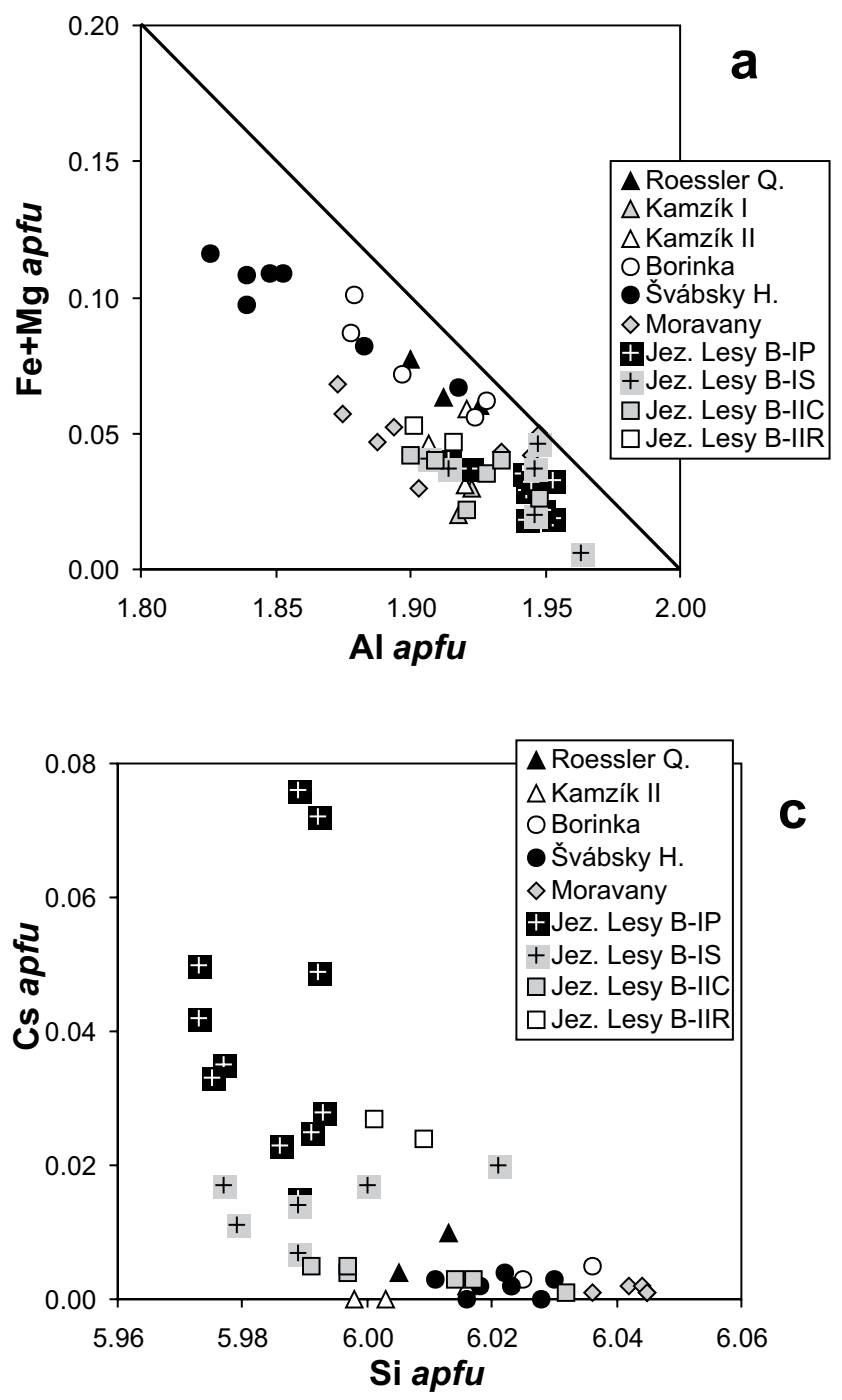

C

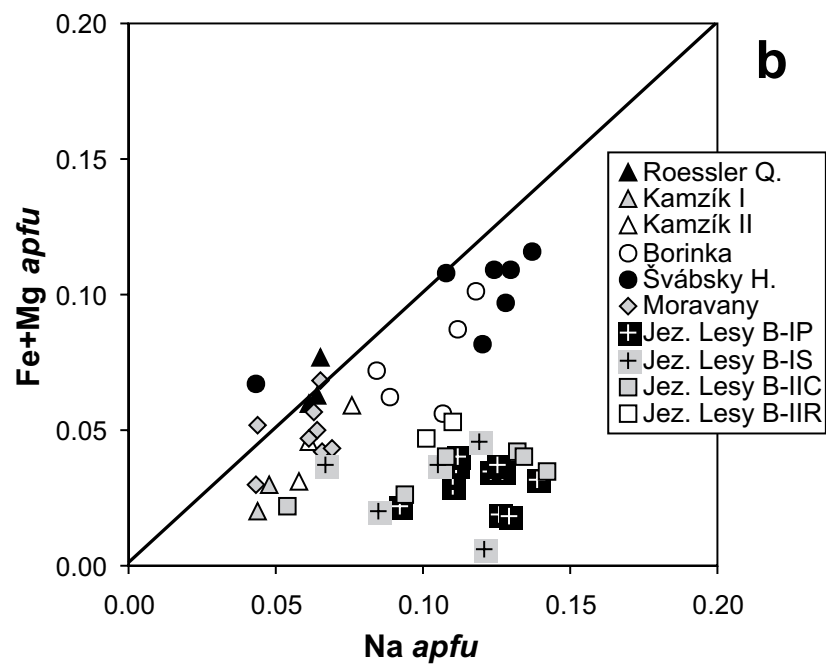

Fig. 4 Substitution diagrams of beryl from granitic pegmatites of the Bratislava and Bojná massifs. a $-\mathrm{Fe}+\mathrm{Mg}$ vs. $\mathrm{Al}$ diagram. $\mathbf{b}-\mathrm{Fe}+\mathrm{Mg}$ vs. Na diagram. c - Cs vs. Si diagram. Diagonal lines represent the ideal exchange vectors. Beryl types: beryl I primary zones (B-IP), beryl I secondary zones (B-IS), beryl II cores (B-IIC), beryl II rims (B-IIR). 
Tab. 3. Unit-cell parameters of beryl from granitic pegmatites of the Bratislava and Bojná massifs (in $10^{-10} \mathrm{~m}$ ).

\begin{tabular}{|c|c|c|c|c|c|c|}
\hline Locality & Sample No. & $a$ & $c$ & $\mathrm{~V}$ & $\mathrm{c} / \mathrm{a}$ & type \\
\hline Roessler Quarry & BM-3 & $9.2116(3)$ & $9.1977(9)$ & $675.88(7)$ & 0.9985 & normal \\
\hline Kamzík I & BM-8 & $9.2036(5)$ & $9.1858(5)$ & $673.84(6)$ & 0.9981 & normal \\
\hline Kamzík II & BM-23 & $9.2175(2)$ & $9.1981(3)$ & $676.79(4)$ & 0.9979 & normal \\
\hline Borinka & BM-9 & $9.2145(6)$ & $9.1915(6)$ & $675.86(6)$ & 0.9975 & normal \\
\hline Švábsky Hill & BM-21 & $9.2248(3)$ & $9.2132(2)$ & $678.98(4)$ & 0.9987 & normal \\
\hline Jezuitské Lesy B-I & BM-22a & $9.2204(4)$ & $9.2172(4)$ & $678.62(6)$ & 0.9997 & tetrahedral \\
\hline Jezuitské Lesy B-II & BM-22b & $9.2246(6)$ & $9.2091(5)$ & $678.64(8)$ & 0.9983 & normal \\
\hline
\end{tabular}

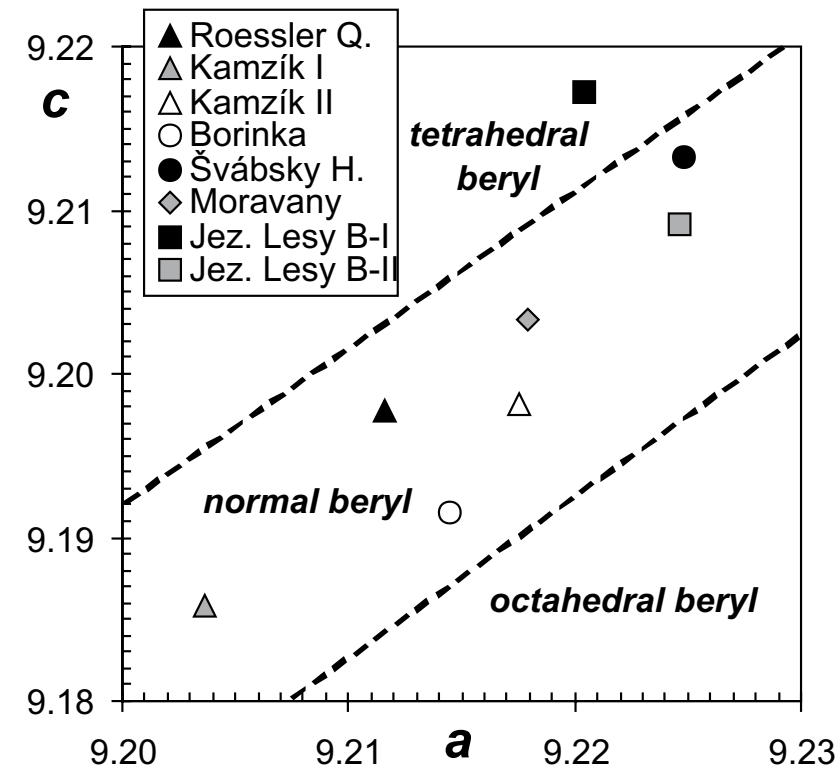

Fig. $5 c$ vs. $a$ unit-cell diagram of beryl from granitic pegmatites of the Bratislava and Bojná massifs (in $10^{-10} \mathrm{~m}$ ) with fields of tetrahedral, normal and octahedral beryl types (according to classification of $\mathrm{Au}-$ risicchio et al. 1988).

type in the Na- and Cs-enriched beryl I from the Jezuitské Lesy pegmatite $(c / a=0.9997)$, in contrast to normal beryl type with mixed octahedral and tetrahedral substitutions in the other samples $(c / a=0.9975$ to 0.9985$)$.

\section{Discussion}

\subsection{Beryl occurrence and saturation}

Beryl represents a characteristic accessory mineral in the more evolved Hercynian granitic pegmatites of the Bratislava and Bojná massifs (Uher 1994). It commonly occurs together with $\mathrm{Nb}$-Ta oxide minerals, mainly members of columbite group, rarely also with ferrotapiolite, $\mathrm{Nb}-\mathrm{Ta}$ rutile, titanian ixiolite and secondary $\mathrm{Nb}-\mathrm{Ta}$ oxide phases
(Uher et al. 1994, 1998a, b, 2007; Uher and Broska 1995; Novák et al. 2000). Consequently, the mineral association, mineral chemistry and petrologic features place these pegmatites within the beryl and beryl-columbite subtypes of the rare-element LCT family of pegmatites in the classification of Černý and Ercit (2005).

Average Be concentrations in the parental granites of the Bratislava Massif attain c. 4 ppm and show an increasing trend with magmatic fractionation, from $3.0 \mathrm{ppm}$ in tonalites to $5.9 \mathrm{ppm} \mathrm{Be}$ in quartz-rich leucogranites (Cambel and Vilinovič 1987). Granitic rocks of the Bojná Massif achieve $3.1 \mathrm{ppm}$ Be on average (Uher 1991). These values are comparable to other common S-type granitic rocks, as well as the average crustal abundance (e.g., London and Evensen 2002; London 2005). Average Be concentrations in common granitic pegmatites attain 3.8 and 3.4 ppm Be for the Bratislava and Bojná massifs, respectively (Cambel and Vilinovič 1987; Uher 1991). Relatively less-evolved pegmatites with scarce beryl and no $\mathrm{Nb}$-Ta oxide minerals show low Be concentrations of less than $20 \mathrm{ppm}$, whereas more evolved, beryl-bearing pegmatites with Ta-rich oxide minerals (ferrotantalite, ferrotapiolite, ferrowodginite) contain $\sim 60$ to $230 \mathrm{ppm}$ Be (Moravany nad Váhom and Jezuitské Lesy).

According to recent experimental study, a hydrous haplogranitic melt could become saturated in beryl at $c$. 100-400 ppm Be at $700{ }^{\circ} \mathrm{C}$ and $200 \mathrm{MPa} \mathrm{P}_{\mathrm{H} 2 \mathrm{O}}$ (Evensen et al. 1999; London 2005). During the initial stage of the melt crystallization, $\mathrm{Be}$ is incorporated into the major rock-forming minerals, especially plagioclase and muscovite. However, after crystallization of alkali feldspars and muscovite, upon cooling to $600-400{ }^{\circ} \mathrm{C}$, the pegmatite melt becomes saturated in beryl at only $\sim 60-40 \mathrm{ppm} \mathrm{Be}$ (London and Evensen 2002; London 2005). The gradual increase in Be concentrations from $\sim 3-6 \mathrm{ppm}$ in granitic rocks of the Bratislava and Bojná massifs is consistent with the model of magmatic fractionation whereby the minimum beryl saturation threshold $(\sim 70 \mathrm{ppm} \mathrm{Be})$ is reached after $>95 \%$ of the parental magma crystallization (London and Evensen 2002; London 2005). 


\subsection{Compositional variations and evolution of the beryl}

Variations in beryl composition, especially in $\mathrm{Na}, \mathrm{Li}, \mathrm{Cs}$, $\mathrm{Fe}$ and $\mathrm{Mg}$ concentrations, could be indicative of mineral and host-rock fractionation and evolution. Beryl composition and unit-cell parameters document a more evolved character of the Moravany nad Váhom and especially Jezuitské Lesy pegmatites in comparison with the rest of the investigated localities (Tab 1-3, Figs 4-6). Beryl from the Moravany nad Váhom pegmatite shows the highest Li content (up to $5600 \mathrm{ppm}$ ), however it contains only $\sim 100$ to $350 \mathrm{ppm}$ Cs and relatively high $\mathrm{Li} / \mathrm{Cs}$ ratio (1.0 to 42; Tab. 2). In contrast, beryl I from the Jezuitské Lesy pegmatite shows high Cs concentration ( $\sim 5700$ to 9800 ppm by LA-ICP-MS; $\sim 1$ to 2 wt. \% $\mathrm{Cs}_{2} \mathrm{O}$ in some zones by EMPA) but it displays relatively low Li concentra- tion ( $\sim 400$ to $500 \mathrm{ppm})$ and very low $\mathrm{Li} / \mathrm{Cs}$ ratio (0.04 to 0.08 ; Tab. 2). Such Li anticorrelation with Cs in beryl can be explained by specific local sources and geochemical specialization of each pegmatite, rather than by a fractionation process with concomitant by increasing $\mathrm{Li}$ and Cs concentrations in the mineral.

Generally speaking, evolution trends of the investigated beryl tend to Na- and Cs-rich and Mg-poor compositions with decreasing $\mathrm{Mg} / \mathrm{Fe}$ and increasing $\mathrm{Cs} / \mathrm{Na}$ ratios (Fig. 6). This assumption is clearly supported by the bulk-rock compositions as well as associated mineral compositions, especially of $\mathrm{Nb}-\mathrm{Ta}$ oxides. Beryl is the only identified rare-element mineral at the Roessler quarry, Kamzík II, Borinka and Švábsky Hill, and rare ferrocolumbite to ferrotantalite has been described at the Kamzík I pegmatite. More evolved, Fe- to Mn-dominant members of columbite-group minerals (ferrocolumbite to
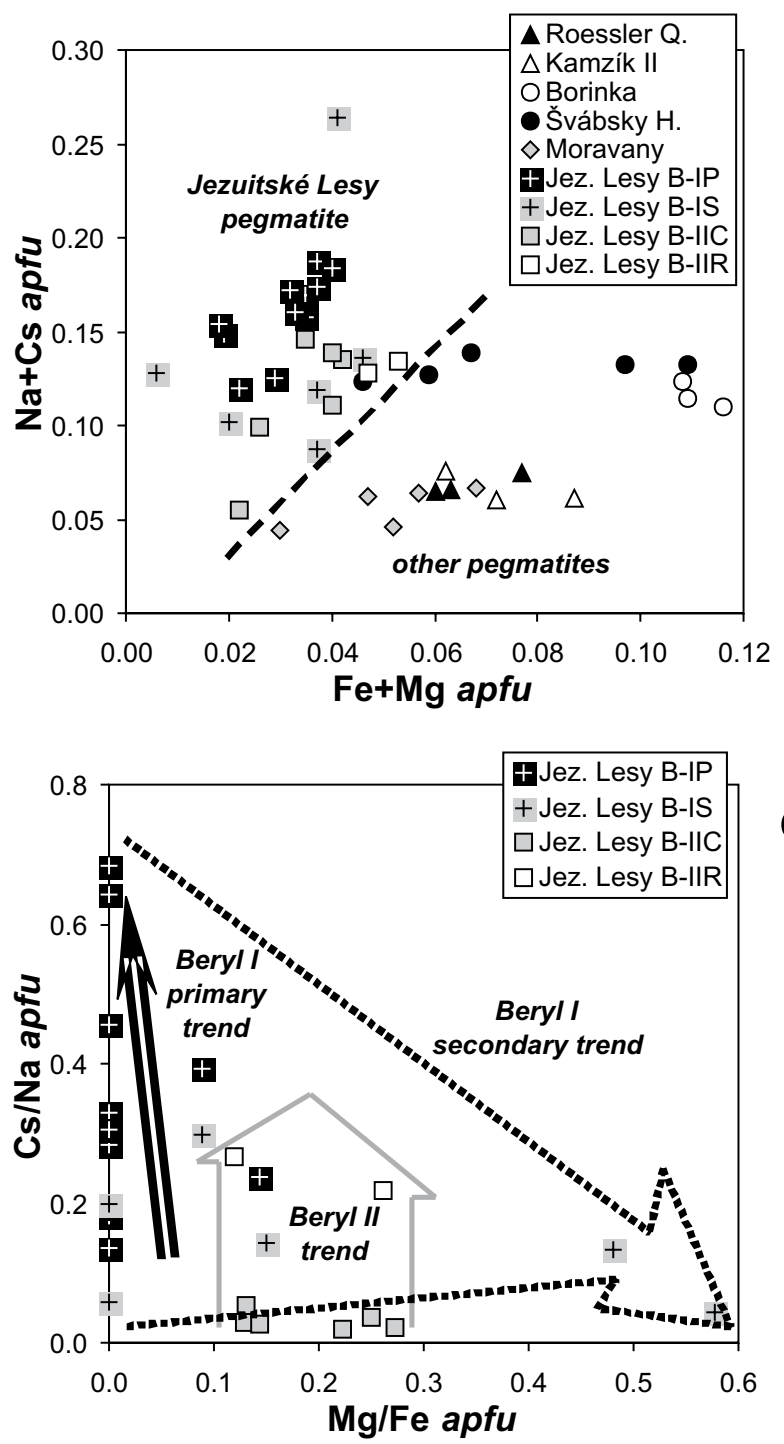

a

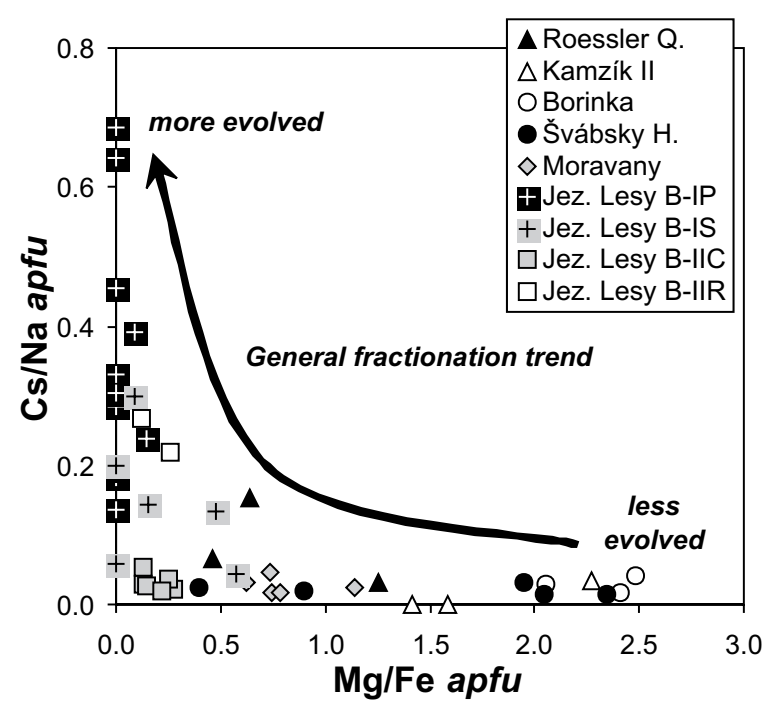

Fig. 6 Composition and compositional trends of beryl from granitic pegmatites of the Bratislava and Bojná massifs. a $-\mathrm{Na}+\mathrm{Cs}$ vs. $\mathrm{Fe}+$ $\mathrm{Mg}$ diagram. $\mathbf{b}-\mathrm{Cs} / \mathrm{Na}$ vs. $\mathrm{Mg} / \mathrm{Fe}$ diagram of beryl from all studied pegmatites. $\mathbf{c}-\mathrm{Cs} / \mathrm{Na}$ vs. $\mathrm{Mg} / \mathrm{Fe}$ diagram of beryl I and II from the Jezuitské Lesy pegmatite. Beryl types: beryl I primary zones (B-IP), beryl I secondary zones (B-IS), beryl II cores (B-IIC), beryl II rims (B-IIR).

manganotantalite) in association with ferrotapiolite occur in the Moravany nad Váhom pegmatite (Uher et al. 1994; Uher and Broska 1995; Novák et al. 2000). The most fractionated and complex assemblage of ferrocolumbite to manganotantalite, ferrotapiolite and ferrowodginite appears in the Jezuitské Lesy pegmatite (Uher and Chudík 2009). In addition, the pegmatite contains Rb- and P-rich K-feldspar and Mn-rich fluorapatite (with up to $10 \mathrm{wt}$ \% $\mathrm{MnO})$. These phases indicate a relatively higher degree 
of magmatic fractionation in comparison to the other localities.

The fractionation trend of beryl, towards $\mathrm{Na}, \mathrm{Li}, \mathrm{Cs}-$ rich and $\mathrm{Fe}-\mathrm{Mg}$-poor composition, is well documented in rare-element pegmatites worldwide (e.g., Černý 1975, 2002; Aurisicchio et al. 1988; Deer et al. 1997; Lodziński 2007; London 2008). However, this general trend could be more complex in some pegmatites. Besides of the anticorrelation between Li and Cs, both beryl I and II appear in the Jezuitské Lesy pegmatite, each with different composition and evolution trend (Fig. 6c). The steep increase of $\mathrm{Cs}(\mathrm{Cs} / \mathrm{Na})$ and very low $\mathrm{Mg} / \mathrm{Fe}$ ratio is a primary magmatic trend characteristic of beryl I, whereas secondary, probably post-magmatic partial dissolutionreprecipitation processes led to the formation of Cs- and $\mathrm{Cs} / \mathrm{Na}$-poor beryl with distinctly higher $\mathrm{Mg} / \mathrm{Fe}$ ratio. Beryl II, associated with saccharoidal albite and cleavelandite, shows an increasing $\mathrm{Cs} / \mathrm{Na}$ and relatively uniform $\mathrm{Mg} / \mathrm{Fe}$ ratio (Fig. 6c). Consequently, compositional variations of beryl in moderately fractionated, beryl-columbite subgroup of granitic pegmatites could serve as a useful tool in understanding the degree of fractionation as well as its magmatic and post-magmatic evolution.

Acknowledgements. The authors thank the reviewers L. Groat, H. Marschall, the Guest Editor P. Nabelek, and Editor-in-Chief V. Janoušek for constructive criticism that improved the manuscript. We also thank P. Konečný and D. Ozdín for the electron-microprobe assistance, and J. Fridrichová for data preparation. This work was supported by the Slovak Research and Development Agency under the contract No. APVV-0557-06, APVV-VVCE-0033-07 SOLIPHA and VEGA grant No. 1/0287/08.

\section{References}

Aurisicchio C, Fioravanti G, Grubessi O, Zanazzi PF (1988) Reappraisal of the crystal chemistry of beryl. Amer Miner 73: 826-837

Broska I, Uher P (1995) Pegmatites in two suites of Variscan orogenic rocks (Western Carpathians, Slovakia) Mineral Petrol 55: 27-36

BROSKA I, UHER P (2001) Whole-rock chemistry and genetic typology of the West-Carpathian Variscan granites. Geol Carpath 52: 79-90

CAmbel B, Vilinovič V (1987) Geochemistry and Petrology of the Granitoid Rocks of the Malé Karpaty Mts. Veda, Bratislava, pp 1-248 (in Slovak with English summary)

ČERNÝ P (1975) Alkali variations in pegmatitic beryl and their petrogenetic implications. Neu Jb Mineral, Abh 123: $198-212$

ČERNÝ P (1989) Characteristics of pegmatite deposits of tantalum. In: Möller P, Černý P, SAupé F (eds) Lan- thanides, Tantalum and Niobium. Springer-Verlag, Berlin, pp 195-239

ČERNÝ P (2002) Mineralogy of beryllium in granitic pegmatites. In: GRew ES (ed) Beryllium: Mineralogy, Petrology and Geochemistry. Mineral Soc Amer Rev Mineral Geochem 50: pp 405-444

ČERNÝ P, ERCiT TS (2005) The classification of granitic pegmatites revisited. Canad Mineral 43: 2005-2026

Deer WA, Howie RA, Zussman MA (1997) Rock-forming Minerals. Volume 1B, Disilicates and Ring Silicates. The Geological Society, London, pp 1-629

EvenSEn JM, London D, WendLANDt RF (1999) Solubility and stability of beryl in granitic melt. Amer Miner 84: 733-745

Fiala F (1931) Some mineralogical findings from the Žiar Mountains. Sbor Prírod Odb Slov Vlatived Muz Bratislava 1924-1931: 24-27 (in Czech)

Finger F, Broska I, Haunschmid B, HrašKo L', Kohút M, Krenn E, Petrík I, Riegler G, Uher P (2003) Electronmicroprobe dating of monazites from Western Carpathian basement granitoids: plutonic evidence for an important Permian rifting event subsequent to Variscan crustal anatexis. Int J Earth Sci 92: 86-98

GaRgulák M, VANeK J (1989) Beryl - a first finding from the Malé Karpaty pegmatites. Mineralia Slov 21: 426 (in Slovak)

Holland TJB, Redfern SAT (1997) Unit cell refinement from powder diffraction data: the use of regression diagnostics. Mineral Mag 61: 65-77

Korikovsky SP, CAmbel B, Miklóš J, JanÁK M (1984) Metamorphism of the Malé Karpaty Crystalline Complex: stages, zonality, relationship to granitic rocks. Geol Zbor Geol Carpath 35: 437-462 (in Russian)

Krist E, Korikovskij SP, Putiš M, Janák M, Faryad SW (1992) Geology and Petrology of Metamorphic Rocks of the Western Carpathian Crystalline Complexes. Comenius University, Bratislava, pp 1-324

ŁoDZIŃSKI M (2007) Mineralogical study of beryls from the Polish and Czech parts of the Sudety Mts. Wydawnictwo Oddziału Polskiej Akademii Nauk, Kraków, pp 1-179 (in Polish with English summary)

LoNDON D (2005) Geochemistry of alkalis and alkaline earths in ore-forming granites, pegmatites, and rhyolites. In: LinNen RL, SAMSON IM (eds) Rare-element Geochemistry and Ore Deposits. Geological Association of Canada, Short Course Notes 17, Ottawa, pp 25-69

London D (2008) Pegmatites. Can Mineral Spec Publ 10, Mineralogical Association of Canada, Québec, pp $1-347$

LONDON D, EVENSEN JM (2002) Beryllium in silicic magmas and the origin of beryl-bearing pegmatites. In: GREw ES (ed) Beryllium: Mineralogy, Petrology and Geochemistry. Mineral Soc Amer Rev Mineral Geochem 50: pp 445-486 
NovÁk M, Uher P. ČERnÝ P, Siman P (2000) Compositional variations in ferrotapiolite + tantalite pairs from the beryl-columbite pegmatite at Moravany nad Váhom, Slovakia. Mineral Petrol 69: 295-306

Petrík I, Kohút M, Broska I, BezÁK V, HrašKo L', JanÁK M, Plašienka D, Uher P, Poller U, Todt W, Nabelek P, RECIO C (2001) Granitic plutonism of the Western Carpathians. Guidebook to Eurogranites 2001. Geological Institute of Slovak Academy of Sciences and Geological Survey of the Slovak Republic, Bratislava, pp 1-116

PitoñÁK P, JANÁK M (1983) Beryl - a new mineral of the Nízke Tatry pegmatites. Mineralia Slov 15: 231-232 (in Slovak)

Pouchou JL, PichoIr F (1985) "PAP“ $\varphi(\rho Z)$ procedure for improved quantitative microanalysis. Microbeam Anal 20: $104-105$

Uher P (1991) Be-Nb-Ta granitic pegmatites - a new type of rare-element mineralization in the Western Carpathians. Geol Carpath 42: 331-339

Uher P (1994) The Variscan West-Carpathian granitic pegmatites: mineralogy, petrogenesis and relationship to pegmatite populations in the Eastern Alps and Romanian Carpathians. Geol Carpath 45: 313-318

Uher P, Benko P (1997) Beryl-columbite pegmatite in the Dúbrava deposit, Nízke Tatry Mountains. Natura Carpat 38: 181-184 (in Slovak)
Uher P, Broska I (1995) Pegmatites in two suites of Variscan orogenic rocks (Western Carpathians, Slovakia). Mineral Petrol 55: 27-36

Uher P, Chudík P (2009) Devín, Jezuitské Lesy: a rare-element granitic pegmatite with $\mathrm{Be}-\mathrm{Nb}-\mathrm{Ta}$ mineralization. In: Kонúт M, Šmon L (eds) Joint Geological Congress of the Czech and Slovak Geological Societies, Abstract volume and Excursion guide. Geological Survey of the Slovak Republic, Bratislava, pp 248-251 (in Slovak)

Uher P, ČERnÝ P, NovÁK M, Siman P (1994) Niobiumtantalum minerals from granitic pegmatites in the Malé Karpaty, Považský Inovec and Žiar Mountains, Western Carpathians, Slovakia. Mineralia Slov 26: 157-164

Uher P, Černý P, Chapman R, HAtÁr J, Miko O (1998a) Evolution of $\mathrm{Nb}-\mathrm{Ta}$ minerals in the Prašivá granitic pegmatites, Slovakia: I. Primary Fe, Ti-rich assemblage. Canad Mineral 36: 525-534

Uher P, Černý P, Chapman R, Határ J, Miko O (1998b) Evolution of $\mathrm{Nb}-\mathrm{Ta}$ minerals in the Prašivá granitic pegmatites, Slovakia: II. External hydrothermal $\mathrm{Pb}, \mathrm{Sb}$ overprint. Canad Mineral 36: 535-545

Uher P, ŽitŇAn P, Ozdín D (2007) Pegmatitic Nb-Ta oxide minerals in alluvial placers from Limbach, Bratislava Massif, Western Carpathians, Slovakia: compositional variations and evolutionary trend. J Geosci 52: 133 141 